\title{
日本教育心理学会総会20周年記念行事
}

\section{I 特別掼演「教育心理学の問題と研究法」}

城 戸幡太 郎

わたくしは，本会の会員でありますので，一会員と して, 研究発表をするつもりでしゃべりますから，み なさん御遠虑なく御批判なり御意見をたまわりたいと 思っております。この問題を選びましたのは, 現在, 高等学校の校長をやって括り, 教育課程の自主編成を めざしており，その点について，いろいろ考えさせら れることがあるので, こういう話題を提案するわけで す.

実は, 心理学とは, みな何々心理学といわれますが, それは第 1 に心理学の方法, 原理によって分類される からです。たとえば教育心理学とか, あるいは動物心 理学とか, 性格心理学々か, 言語心理学, 行動心理学, 形態心理学, そらいらふらなものは, 心理学の方法, 原理から区別されるむのであります。

それから心理学の研究法による分類もあります. 説 明心理学だとか, 了解心理学だとかまた実験心理学と か, そらいらすのは, みな心理学の研究法によるもの であります。

それから，また，研究対象によるものもあります。 そしてここで問題にしたいのは, 対象と研究法が混同 する,といら語弊がありますが，それが同時に考えら れておるすのであります。それは，研究対象に限るの ではなくて，それに関連しての研究法を，それに加え られているものです. 対象によるものとしましては, たとえば年齢別によりまして, 児童, 青年の心理学と いらようなるのがあります。それに対して，いわゆる 発達心理学といらのは, 必ずしも対象にだけ関係する ものではなくて，それに対する方法も問題にするわけ であります。

そういう点で一般的に申しますと, 対象と方法を兼 ねたものといたしましては, 理論心理学と応用心理学 といらものが区別されて拈ります.これは一般的には, 科学が, 理論科学と応用科学に区別されていることに よるもので, 産業心理学とか, あるいは犯罪心理学と か, 臨床心理学といらものが研究されており, 教育心 理学も一般的には, 応用心理学のひとつとして考えら れておるように思います。しかし，教育といらのは，
ひとつの社会的な事象とみなしますと，それは社会心 理学の一分野とも考えられますし，また，民族心理学 の一部か, あるいは歴史心理学とも関連してまいるわ けであります。

いずれにいたしましても，人間の精神活動に関係す ることがらを, 心理学の研究対象とみなしますと, そ れに応ずる多種多様の心理学が研究されることになり ます. おそらく, 心理学ほど何々心理学と称せられて, 研究領域が多岐にわたっている学問はないのではない かと思うのです.これは, 心理学がひとつの科学とし て, 科学的方法は認められているにもかかわらず, そ の研究成果が，どうも期待にそわないという理由によ るものではないかと, わたしは思っておるのでありま す.

これは, 今から 8 年ほど前の神戸大学で開かれた総 会でのシンポジゥムで, 教育心理学は実際に役に立っ ているかどうかといらことが問われました。それい答 えはNoでありまして，貢献していないといらのがそ の答えであったのです.

そしてまた, 昨年の日本心理学会で, 肥田野教授が 教育心理学の発達につきまして報告されましたが，そ の教育心理学の研究の動向というもののまとめとし て, 肥田野教授がいって扔られますのは, 今日の教育 心理学研究は, より分析的になり厳密な方法がとり入 れられておるようであるが，教育実践に直接関係する 研究は依然として少ないことも，認められなければな らないと述べられてあるのであります。

実は, 午前中みなさまの御意見を拝聴したのですが， この総会でも教育現場から見た教育心理学が課題に なっております。そして，どうすその結論としては， 教育心理学の今後の発展性が期待されているように 思ったのであります。このような現状を前提としまし て, 特に教育心理学の問題と研究法について, 私見を 述べてみたいと思らのであります。

先ほど述べましたように，科学は理論科学と応用科 学に区別され，応用科学は，科学に対する技術として， 理論科学からは, いくらか軽視された傾向があります 
が, 現在では科学と技術は, 科学技術として統一され technic が technology として科学的に研究されるよ らになったことは, 御承知のとおりであります，応用 といいましても, 誰が何のために科学を応用するのか が問題であります．政治家や企業家は，自分たちの実 用的な価値のために科学を利用することになります. それが，核戦争や公害を起こすことになったのであり ます。それが現在, 科学者の反省と自覚とを促すこと になり，それで科学における理論と応用，また理論と 実践の統一が要求されていると思うのであります。

それを教育の場合について申しますと, 現在, 解決 を必要とする問題は，それが何であるかといえば, 御 承知のように教育の荒廃だとか，あるいは文化の程度 だとかいわれて扣りますが，それは，教育の実際につ いて発見される問題でありまして，その問題が提起さ れるためには，それをどら解決するかといらその解決 を研究するのが科学者でなければならないと思らので あります。

現在, 教育の荒廃の問題といいますが, 直接には, いわゆる落ちこぼれの問題があります。しかし，その 教育の荒廃とか, あるいは落ちこぼれというのは,いっ たいどらして起こってきたか，その原因がどこにある かといらことを問題にしていかなければならない。そ らいら点が実践とかかわりのある心理学であります。 そらいら問題と関係なく，実践とかかわりのない心理 学的な研究課題でありますならば，それがいかに綿密 に科学的な方法によって研究されるとしても, その成 果は，教育の実践には役立たないことになります。そ れで教育の心理学的な研究は, その研究課題が, 教育 の実践に即して生起されていなければならない，そこ に教育心理学の問題があると思うのであります.

教育心理学会の総会は，一年に一度ある. 会員によ る研究発表の場でありますが，その部会がどういうふ らに分かれているかは，そのプログラムを見てもわか りますが，その部会の設定は形式的にならざるを得な い.これは，仕方がないと思らのでありますが，少な くとも, シンポジゥムは, 当面解決を必要とする教育 問題について討議されることが望ましいと思うのであ ります。それで部会としても，教授・学習・測定・評 価・臨床・障害といらようなものがありまして, それ らは, 教育の実践と関係の深い問題ではありますが, 今日のこのプログラムを見ましても, 現在, どうして す解決しなければならないといら問題を設定して, そ れについて解決法を研究された研究発表といらのはあ まりない.ないとはいえませんが，少ないのではない かと思うのです.
しかし、この総会では, 先ほど申しましたように, 特に「教育現場から見た教育心理学」が問題にされて おります。それで, 午前, その部会で, みなさんの御 意見を拝聴したのでありますが，わたくしが考えてい、 るような問題点が, はっきりと打ち出されていたので あります。そういう点で, それではそれをどういらふ らに研究していけば教育心理学の不毛性は解決される のか, その点で, 理論は実際に即したものでなければ ならないといらことはいわれますけれど, それを具体 的に科学的に研究していく場合には, どうしたらいい かといら点がまだ十分に討議されなかったように思わ れます，それで，そのことについて，わたしの見解を 述べてみたいと思います。

教育での教科教育の問題は, 要するに, 教育課程の 編成であるカリキュラム開発 (curriculum development）の問題になるわけです. その点は午前の部会の ほうでも問題にされました。 わたしは，やはりそこに カリキュラム開発の方法として, いったい心理学は, どらいら役割を果たすべきかといら点を考えなければ ならないと思うのです。

一般にカリキュラム開発は, 一方は論理学, 一方は 心理学といらふらに考えられています．論理学と考え られているのは, その教育内容としての教材そのもの のシステムとしての知識体系を問題にする場合には, やはり, 論理学が問題になるからです.しかし, それ を学習させていって, その結果がどうであるかという 点になると，学習の主体である生徒の子どもの考え方 を問題にしなければならない，そこに心理学の問題が あるわけです.カリキュラム開発のために必要な科学 的な研究は, 一方は論理学, 他方は心理学の問題です.

それが, 現在の学力問題の論争をみましても, 教育 学専門の人は論理主義に傾いています。たとえば教材 の内容はどうつくるかなどという点では, どらしても 論理主義にならざるを得ません。午前の部会でも，そ らいう点を評価された方があります。しかし一方にお いて, それをどういうふらに生徒に学習させるか, 学 習の結果がどうであるかといらことは, 学習の主体で ある生徒の考え方, 思考の構造というものが問題に なってくる. それをあまり問題にしないところに，わ たしは問題があるのではないかと思っているのです. それで，それを研究する場合には，どうしても教育課 程の編成，すなわち，カリキュラム開発につながると 思うのです. その研究としては, どうしても, 教授, 学習, 測定, 評価といらものが, それに関連して研究 されなければならないはずです，新しい教育課程の編 成にあたりましては，これまでの授業と学習の結果か 
ら反省すべき点あるいは，新しい心構えが必要になっ てくるのでありますが，どうす，文部省なり，あるい は，日教組で作りました教育課程編成に，果たしてそ れだけの科学的な準備が行われたかどうかということ が問題であります．現在のカリキュラムが果たして妥 当であるかといらためには, やはり, 生徒の学力の評 価をやって, その結果から, それを判断していかなけ ればならないわけです.そらいうことが行われた結果, はたして新しいカリキュラムが開発されたかどらか, また，それに応じて新しい学習指導要領が作られたか ぞらかといらところに問題があると思らのです。この 点につきましては, 今まで,わたしは，いろんな方面 で意見を述べましたが, ここでは, 教育心理学の研究 法をどうしたらよいかということを述べてみたいと思 らのです。

文部省あるいは日教組で作りました教育課程審議会 では, 各専門の教科に関する専門の学者は, 委員とし て選ばれていますけれど, それを年龄の発達や, 個性 に応じてどういうふらにそれを開発していかなければ ならないかは, どうしても心理学の問題になりますけ れど, 心理学者は, 重要な役目を果たするのとしては, 特に選考されておりません，そこに，やはり，問題が あると思います。

今, 学校教育で問題になっておりますのは, 先ほど 申しましたように, いわゆる落ちこぼれの問題です. 御承知のとおり, 文部省では, そのために特別学級を

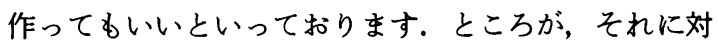
して一般の世論は反対で, 特殊学級を作ってはならな いといっているらしいですね.これはNHKでも，だ いぶ問題にしております。ところが，それが妥当でな いかといらためには，実際そういら落ちこぼれを特別 学級で指導してみて,あるいは,一般の生徒といっしょ に指導してみて, その結果がどうであったかという科 学的な研究の結果は全然問題にされないし, また, 研

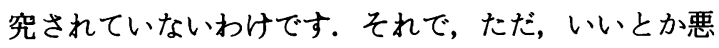
いとか言うのは, 科学的ではないと思うのです。

それから，教育で, 現在問題になっているのは，い わゆる偏差值ですね。 これはかつて, 心理学者が mental test をやるとき，その処理方法として考え出し たものです。それが, 教育の現場で, あるいは, 文部 省あたりで問題にしているかぎり，心理学者はそれを どうすべきかといらことを, 科学的な立場から主張し なければならないはずです，ところが，それがあまり 問題にされない，わたくしは，そこに問題があるので はないかと思らのであります。これは, ひとつの例で すが,こういう問題を解決する場合, 科学的な方法と
しては実験心理学的に研究しなくてはならないと思う のです. 本日の午前中の部会でも, その点で, やはり, ふたつの顔が必要だという意見もありました．理論的 な研究をすることが実際に必要であります。しかし， 同時にその実際問題を解決するためには, 実際に即し た実験的な研究をやっていかなければならないと思ら のであります。それで, 今日も，打話が出ていたので すが, 方法として, ミク口的な実験とマク口的な実験 というふらに対比して両者が必要であるというふらに いわれますが, しかし，わたしは，ミクロとかマク口 とかいう対象の大小によるものではないのではないか と思うのです. 心理学はその方法論的原理によって実 際問題をどう解決するかといらことでありまして，そ の目的によって研究の方法は違らわけです. ミクロと かマクロといらことで区別すべきものでは違らわけで す. その目的に応じて研究法が科学的に考えられなけ ればならないと,わたしは思らのです。ですから, 結 局, わたしの考えでは, 教育心理学的な実験は, 教育 実践を科学的に計画した実験でなければならないと考 えるわけです。ですから，それは，理論と実践との統 一でありまして，科学と技術との統一でもあると考兄 るわけです.

御承知のように心理学者として, アメリカに行きま したドイツの Hugo Münsterbergは, 心理学をアメリ カ式では, general psychology と applied psychology に区別しました。しかし，ドイッ式では，いわゆる精 神の理論と精神の技術 Psychotechnik に区別しまし て精神の技術は, 健康とか経済・法律・教育・芸術・ 科学を問題として研究したわけであります。そして, 彼はPsychotechnik として教育の問題としたのは, 授業法であります。それから今日でも，授業研究とい らものを, 教育心理学の主要な課題として, 授業心理 学とでもいったほうがいいとらような御意見もあり ましたがここれは問題としまして，とにかくMünsterberg が Psychotechnik の問題として特に教育を考 えたのは, いわゆる授業研究であります.

しかし，わたくしといたしましては，特に Münsterberg の考方方で注目すべきと思いますのは，科学 を精神技術学の研究対象としたといらことでありま す. それは科学を研究して, それを発展させるのは, 科学者であり, 科学者としての人間であります.一般 に科学的な研究法としましては, 研究者である科学者 としての人間の主観を超越して，その認識の対象であ るところの理論の妥当性を問題にしております。

心理学では, 心理学者の主観が観察の誤差を生ずる から，その誤差を除去する方法として，平均をとった 
ク, 或いは偏差値を算出したりしますけれどあ, なぜ 誤差が出てくるか，これは人間の主観のはたらきに よって愦差ができるわけでしょう，では，なぜそうい 誤差がでてくるのかといらことを, 個人差の問題に して研究しなくてはならないのです. それは, 実験心 理学の発達が御承知のように, グリニッチ天文台での Maskelyne の観察と, 助手の Kinnebrook の観察結果 が違ってくる，それで問題になりまして，その助手は 解任されたわけです。 そこで，どうしてそういら誴差 が生ずるのかを問題にして, 認識の誤差についての実 験が始められたわけです。 そして, その研究の方法と して視覚と聴覚が一緒になった場合, どらいらことが 生ずるかというような研究が始まったわけで, それが 実験心理学の発達を促進したことになったわけです.

それと同じように，教育の場合においても，教育の 誤差といらものはどらいうものかといらと, ある授業 をしても，きくとわからない，あるいは，まちがって それを答えるといらことは，思考に打ける誤差でしょ う。このようにその誤りを問題にし，それを諨らない よらにする方法を研究することが教育心理学の研究課 題でなければならないと思らのであります。

この点で, 少し歴史的な問題にはいりますけれども, 御承知のようにKant は, 彼の批判哲学で問題にいた しましたのは，人間を超越する理性の普遍性でありま す。しかし，理性といっても，人間の理性は誤りを犯 すことがある. その理由を明らかにして，それを正し く指導していくことを考えなければならないといら立 場から，その方法として彼は，プラグマ的な見地から の人間学 (Anthropologie) を考えたわけです.わたし は, 彼の Anthropologie は, 経験的な心理学と思うの ですが，その方法として Kant は2つの方法を考えま した。ひとつは，人間学的教授学であり，むらひとつ は, 人間学的性格学です.この教授学と性格学を彼の Anthropologie としての心理学の方法といっていいで しょう.心理学の研究法として認めたということです. これは，あまり一般的に問題にされないことでありま すが，わたしはこの点に着目してみたいと思います。 そこに, 心理学の研究法の重要な歴史的な課題がある よらに考えるからなのです.

それはKant と同じ時代でありまして, Kant の影響 を受けたと思われますが, 教育学を創設した Herbart も非常に高く評価しておりますが, August Carus と いう人がおります。この人は, 1770 年から 1809 年でな くなっておりますから，まだ40にならない若さでなく なった天才的な心理学者です.

彼は最初に, 心理史を書いた人ですが, 彼の心理学
は, 人間学としての心理学で, その方法として, 彼は どらいらことを考えたかと申しますと，人間の年齢的 な発達段階を, 幼児, それから小学校の児童, 中学校 の学童, 大学, この 4 段階に年龄の発達段階を分ける のです.そしてそれをObject (対象) と Subject (主体) との関係から指導して行くのです.それで彼が対象と いうのは, 教科の内容としての教材で, それを学習し ていく主体である人間にそれを教育していくための方 法 Method を論じております。しかし，これは教育の 研究ではありません. 彼のいら心理学の研究法として, そらいら方法について論じているのです.

これは, 先ほど申したKant の人間学の方法として, 人間学的教授学をその方法論として考えたということ になると，わたしは考えています，ですから彼の人間 の発達段階は, 教育によるもので, これはKant の人間 学が，その方法として教授学を考えたのに比較すべき ではないかとわたしは思うのであります。ですから， 少なくとも，人間の発達を問題にするならば，その方 法として教育を考えなければならないと思らのであり ます。

そこで,これは心理学であ問題にされておりますよ らに, 発達 development は, 単なる成長 growth では ないと区別されておりますね。そして教育というすの は，その発達の可能性を問題にするといらるらにいわ れております。そうすれば，発達を問題にする発達心 理学は，その方法としては，どらしても教育を問題に しなければならないはずであります。

これは,御承知のように Piaget は,心理学者としまし て発生的な認識論といら立場から，年齢による思考の 発達段階を認めむした. しかし，それが思考の発達で あるか，あるいは発達を可能にする教育を問題にしな ければならないのかといらよらに考えられます。それ を問題にしたのが Piaget の研究を高く評価しながら る，それを批判したソビェトの心理学者であります。 たとえば算数の場合，代数なんていらのは今でもそう ですが, 高等学校にならないと教えませんね. しかし， ソ連では, 代数は算数よりもわかりやすく, 問題を解 決することができる. 小学校の 2 年くらいからやって もいいんだといらふらに考えています。そういうとこ ろに問題があるのです.

だから教育心理学というものは, 教育によってどう 発達を促進していくかといら教育の方法による発達の 可能性を問題にする限り, Kantが申したように，教授 等が人間学の方法であるように，教育は教育心理学の 研究法でなくてはならないのです. その点はひとつ考 えておいてもらいたいと思らのです. 
実は, 教育心理学は, 応用心理学的に教育の問題を 解決するのではなくて, 人間の発達を問題にする限り, 教育を研究の方法として考光る．それによってはじめ て人間の発達といらことが，心理学的に研究されるよ らになると考えられるのであります。このことは, 1964 年の「教育心理学研究」に「教科としての教育心理学 の研究法について」といらテーマで書いておりますか ら，御参照していただければ幸いです。

それで，わたしの考える教授心理学といらのは，そ の研究法として 2 教育を考えるといらことですから, それによって解決しょらとする問題は, 教育の問題で あると同時に, 教育の方法によって解決する問題でな ければならないと考えるわけです。一般に解決を必要 とする教育の問題は多いのですが，それを解決する方 法は，いわゆる project research (計画研究) で，それ は実際問題を解決する方法で，それを解決するために はどらしても心理学だけではなく，それを解決するに 必要な科学的な研究を総合して, 解決にあたらなけれ ばならないわけです。それが計画研究の特色でありま す.

これは, 日本でも最近とりあげられる学際的な研究 でありまして, 教育問題に限らず, 計画研究としては 学際的研究を必要とするのです. 特に教育のような社 会問題をただひとつの科学的な方法によって解決しよ らとするところに, 科学の不毛性が認められるわけで, 学習の問題にしましても, 心理学だけではだめで, 医 学も, ことに精神医学あるいは病理学, そらいうもの も考えていかなければ問題は解决しないといらことで す.ですから, 教育心理学といらすのが, 仮に応用心 理学のひとつとして考えられたとしても, 教育問題を 解決しようとするのなら, 問題解決のために片手落ち の研究になってはならないと思うのです。

これは心理学だけの問題ではなくて, 科学的研究の 一般の課題でして, 一般には, 大学における学問のセ クショナリズムによるとわたしは思らのです。 そこに 現在問題になって剅ます大学改革のキーポイントが あるとわたしは考えておるのであります。しかし，大 学の改革といらものは, なかなか容易ではありません. それで，そらいらことを日本の各大学から集まって研 究される学会では, 解決を必要とする問題について総 合的に研究を計画する学会が開催されなければならな いと思うのです.

それでこれも何年以前になるか御承知のように，心 理学会には, 日本心理学会, 応用心理学会もあれば, 犯罪心理学会, 教育心理学会, 臨床心理学会それに, 産業心理学会とか, いろんな学会がありますが、それ
らをどうしても総合統一しなくてはならないと考えら れて, 心理学会の総合統一を提案したのは, この教育 心理学会たっったと思うのです，それで, 教育心理学会 が率先して、イニシァチブをとって，まず心理学会を 改組し，それから統一をやれといらことをいったわけ です。これは 10 年も前にです。ところが，現在にな りましてもあいかわらず，みんな学会はそれぞれバラ バラで, 日本心理学会として統一されておりません. これは, 心理学そのもののセクショナリズムで, そう いっては悪いですが，心理学者のセクショナリズムで はないかと思うのであります。

それで，わたしは教育心理学会としましても，今ま では応用心理学的な考え方から教育の問題を心理学的 に研究するんだといらふらに考光られておって，その 心理学的な研究の方法は, 非常に科学的であるという のではなく，その方法としてKant のいったような意 味で, 教育そのものの方法, 教育, 教授法といってい いのですが，それを教育心理学の方法として考えると いらことが必要ではないかと思うのです.

わたしがいいたいのはこの点でありまして, それで その点で問題になるのは, 教員養成では教育心理学は, 必修科目として定められておりますが，しかしそれに よって何が学習されているか問題があります. 教育実 習のためには, 教授法といらすのがやはり実習されて おりましょう。しかし, 教育と学習の関係は, 教師と 生徒の人間関係が，相互の表現と理解の相互関係によ るものです。それを科学的に問題にしたのが御承知の ようにフィードバックを問題にしたサイバネティック スであります。そして, それによって情報科学が発達 しました．わたしは，授業研究につきましては，そう いら意味で研究していかなくてはならない. 教師と生 徒の相互理解，相互的な授業との関係を問題にしてい かなくてはならないと思らのであります。

そうしますと問題となるのは, 今日の午前の分科会 でも討論の対象となりましたが, 教科教育として非常 に必要なのは, むしろ教科の内容を教材としてどら組 みあわせるかといらことです。 それはそれぞれの教科 の専門がたとえば, 理科で物理を教えるといらときに は, 物理学専門の方が, 化学になれば, 化学の専門家, 生物なら生物, 地学なら地学の専門の者が, その教科 その内容を問題にすることが望ましいといら意見があ ります。わたしは，それは必要ではあるが，先はど申 しましたように, カリキュラムの開発としては, 論理 学と心理学が必要であり, その教育内容としての教材 が教育のためのものであれば, それは論理学的に正し い知識体系であることが必要ですが, それは生徒が学 
習するものとしては, それが学習を可能にする学力即 ち生徒の学習能力がふさわしいかどうかが問題にされ なければなりません.それは, 心理学としては学習させ られる教材は学習の対象であり, 心理学的には刺激の 内容で, それを学習することは知覚することでもあり, そのために刺激錯誤も起こるのです.これは先に示した 一人一人知測に打ける人差の問題に比すべき問題で, 刺激錯誤に相応する教材錯誤む起こるので,ここに思考 の心理学としては, 特に性格の問題が研究されなけれ ばならないのです。いま問題になっている落ちこぼれ についていえば, なぜ落ちこぼれるか，そらいうとこ ろを問題として研究するのが教育心理学の研究課題だ と思うのです。これは, わかりきったことだとわたく しは思っていたのですが, どらも最近の学力問題につ いての論争は, 教育学専門のものはどちらかといえば 授業研究は，その論理主義的な立場を強調します。そ れは必要です。しかし，彼らは同時にそれを学習する 主体である生徒の心理学的な構造は, あまり問題にし ない.だからそのほうの研究は進んでいません，少な くとも日本では生徒の思考力の心理学的な構造に関す る研究は足らないように思らのです.

それでそれも時間がきましたので結論を申したいと 思いますが, わたしはそらいら意味で, 教育心理学の 研究の方法は計画研究でなければならないと考方るわ けです. そして project method は, 小学校段階からも 問題になりますが，それは生徒の自発的精神を養らた めの方法で, それは計画研究の基礎とはなりますが, その科学的方法は大学の学生段階において強調する必 要があると思らのです。みんなそれぞれ専門化された 学問で, 専門的に研究して扬りして, それがバラバ ラになってひとつも総合的にまとまらず, 計画性を もって問題を解決しようといらようなことはない。そ らいう点で, むしろ大学の学生の指導として project method をやることによって, 計画研究が進んでいく のではないかと思います。

そういう点でわたくしは今, 一私立高校の校長とし て研究を進めておりますのは, 教育課程の自主編成に ついてです。それにつきまして具体的に打話しょうと 思いましたけれど，時間になりましたので，その点は 省きますが,この研究の方法としては, 一般に科学 的な実験として考えられて抲ります仮説実験, これを わたしはわたしの学校でも教師たちに強調しておるわ けです.

カリキュラムは考えます．しかしそれは理論的に考 えたものです．理論的に考えられたカリキュラムがは たして妥当であるか, 妥当でないかということは, 教 育の実践によって証明されるのです。それで，わたし は校長として, 自分の私案でカリキュラム開発の原 則を考えました。これはひとつの作業仮説で，その作 業仮説を実践によって，それが妥当であるか妥当でな いかを実証していくのが教育の実験でなければならな い.だから一般に理科教育の指導法としては, 仮説実 験が認められていますが, この仮説実験は科学的研究 の方法であり, 教育の研究もそれが科学的研究である からには仮説実験はとり入れていかなければならな い.だから,どらしても理論と実際との関係は, 理論 はひとつの仮説であります，ただ，理論として仮説を たてたその仮説が妥当であるか妥当でないかといらこ とを, 実践によって実験的に証明して行くのだ，そう いら態度は教育課程の研究にも適用されなければなら ないといらことを知っておいてもらいたいと思うの で，実はその点を申したかったのですが，わたしがこ こで教育心理学の研究法として考えていたださたいの は, そらいら意味での理論と実践を統一し発展させる 仮説実験であります。

どらもありがとうございました。 